\title{
Pengembangan Video Iklan Layanan Masyarakat Mengenai Keselamatan Berkendara Pada Polres Parepare Sebagai Media Informasi Menggunakan Teknik Motion Graphic dengan SWISHMAX 4
}

\author{
Imam Nur Ihsan ${ }^{1}$, M. Yusuf Mappeasse ${ }^{2}$, Mustamin ${ }^{3}$ \\ ${ }^{123}$ Jurusan Teknik Informatika dan Komputer, Universitas Negeri Makassar \\ ${ }^{1}$ imamnurihsan2826@gmail. com
}

\begin{abstract}
Abstrak - Pengembangan Video Iklan Layanan Masyarakat Mengenai Keselamatan Berkendara Pada Polres Parepare Sebagai Media Informasi Menggunakan Teknik Motion Graphic dengan Swishmax 4. Skripsi. Penelitian ini bertujuan menghasilkan pengembangan video iklan layanan masyarakat mengenai keselamatan berkendara menggunakan teknik motion graphic serta mengetahui tanggapan masyarakat mengenai video iklan layanan masyarakat tersebut. Jenis penelitian yang digunakan yaitu penelitian dan pengembangan (Research and Development) dengan menggunakan model pengembangan four-D (Define, Design, Development, Dessiminate). Subjek penelitian ini adalah ahli materi, ahli media, dan masyarakat Kota Parepare. Data penelitian diperoleh dari hasil angket validasi ahli materi, angket validasi ahli media, dan angket tanggapan masyarakat. Data hasil penelitian dianalisis dengan analisis deskriptif kuantitatif. Dari hasil penelitian terhadap video iklan layanan masyarakat berdasarkan penilaian ahli materi mendapatkan penilaian sangat layak, penilaian ahli media mendapatkan penilaian sangat layak, serta hasil uji coba kelompok kecil dan uji coba lapangan video iklan layanan masyarakat mendapatkan respon positif dari masyarakat Kota Parepare. Dari penilaian ahli media, ahli materi, dan tanggapan masyarakat, video iklan layanan masyarakat mengenai keselamatan berkendara menggunakan Teknik Motion Graphic dengan swishmax 4 termasuk dalam kategori layak digunakan.
\end{abstract}

Kata kunci: Video, Motion Graphic, Keselamatan Berkendara, Swishmax 4.

\section{PENDAHULUAN}

Mengerti akan semua peraturan berkendara merupakan sebuah hal yang harus dipahami oleh semua pengguna jalan terutama pengendara yang setiap harinya memulai aktifitasnya di jalan. Ada rambu-rambu lalu lintas dan marka jalan yang harus dimengerti oleh setiap pengendara, bila tidak kita patuhi atau bahkan kita langgar secara sengaja maka sanksinya bukan hanya surat tilang dari polisi lalu lintas tetapi bisa saja berakibat sebuah kecelakaan yang tentunya tidak hanya merugikan kita sendiri tetapi juga orang lain. Selain menaati rambu-rambu lalu lintas dan marka jalan ada juga beberapa hal yang harus kita lakukan seputar kelengkapan berkendara, seperti contohnya memakai helm Standar Nasional Indonesia (SNI), menyalakan lampu di pagi hari dan memakai jaket untuk keselamatan pengendara motor, memakai sabuk pengaman untuk pengendara mobil, yang telah diatur dalam Undang-Undang Nomor 22 Tahun 2009 Tentang Lalu Lintas (Widisindia, 2014).

Kecelakaan lalu lintas di jalan raya merupakan penyumbang angka kematian terbesar di dunia. World Health Organization (WHO) mencatat hampir 3.400 orang meninggal di jalan dunia setiap hari. Puluhan juta orang terluka setiap tahun. Anak, pejalan kaki, pengendara sepeda dan orang tua paling rentan dari pengguna jalan. Secara umum Kepolisian Republik Indonesia (Polri) mencatat 98.419 kecelakaan pada tahun 2017. Sedangkan untuk Provinsi Sulawesi Selatan sendiri, terjadi sekitar 47 kecelakaan. Data yang diperoleh akibat kecelakaan lalu lintas di Provinsi Sulawesi Selatan, bahwa jumlah total korban luka ringan sebanyak 4.509 orang, korban luka berat sebanyak 656 orang, dan korban meninggal dunia sebanyak 951 jiwa (Fisu, 2019).

Menurut data hasil observasi Satlantas Polres Kota Parepare pada tahun 2016 sampai 2018 mencatat terjadi 653 kecelakaan lalu lintas dengan jumlah meninggal dunia sebanyak 79 jiwa, luka berat sebanyak 11 orang dan luka ringan sebanyak 563 orang (Satlantas Polres Parepare, 2018). Dari data di atas, banyaknya korban dan kerugian yang ditimbulkan, baik akibat hilangnya nyawa, maupun biaya yang diperlukan untuk pengobatan dan rehabilitasi penderita, maka kecelakaan lalu lintas termasuk dalam masalah kesehatan masyarakat dan memerlukan perhatian serius dari semua pihak yang terkait.

Pemerintah sebagai penyelenggara negara, turut berupaya untuk meminimalisir tingginya angka kecelakaan di Indonesia Upaya yang dapat dilakukan agar masyarakat dapat meminimalisir tingginya angka kecelakaan dan meningkatkan persentase keselamatan pada saat berkendara yaitu dengan melakukan sosialisasi keselamatan berkendara, sebagai rangkaian tindakan komunikasi yang terencana dengan tujuan menciptakan efek tertentu pada sejumlah besar khalayak yang dilakukan secara berkelanjutan pada kurun waktu tertentu. Sosialisasi dilakukan dalam upaya untuk mengubah prilaku, sikap bertindak, tanggapan, persepsi, hingga membentuk opini publik yang positif, kemudian diharapkan menjadi pendukung dalam program yang akan dilaksanakan suatu lembaga (Venus dalam Kunarto, 2004).

Iklan layanan masyarakat sebagai siaran iklan nonkomersial yang disiarkan melalui media cetak atau pun elektronik dengan tujuan memperkenalkan, memasyarakatkan, dan atau mempromosikan gagasan, cita-cita, anjuran, dan pesan-pesan lainnya kepada masyarakat untuk mempengaruhi khalayak agar bertingkah laku sesuai dengan pesan iklan tersebut (Dwihantoro, 2010). Selain medianya yang mudah diakses, adanya berbagi jenis iklan layanan masyarakat ini diharapkan dapat memberikan informasi positif dan dampak yang positif bagi masyarakat. Masyarakat diharap bisa dengan mudah memahami isi dari iklan tersebut.

Animasi adalah media yang dapat memaparkan ide-ide kreatif dengan tampilan visual yang tiada batas. Jadi imajinasi apapun dari sang creator dapat diwujudkan melalui media ini dan animasi bisa dijadikan sebagai media relaksasi. Dengan bantuan komputer dan grafika komputer, pembuatan film animasi menjadi sangat mudah dan cepat. Aplikan animasi ada dua jenis, yaitu animasi dalam bentuk nondigital dan animasi dalam bentuk digital. Animasi dalam bentuk nondigital merupakan hasil akhir animator menampilkan gambar-gambar dan pergerakannya dalam 
bentuk cetak yang lebih umumnya pada kertas-kertas yang banyak. Sedangkan animasi dalam bentuk digital berbanding terbalik dengan aplikasi cetak, yaitu hasil akhir media yang digabungkan animator dalam menampilkan gambar-gambar bergeraknya melalui digital, sehingga gambar-gambar yang digunakan tahap awal pembuatannya adalah sketsa tangan, foto, atau apapun yang berhubungan dengan media cetak, tetapi diakhiri atau ditampilkan dalam media digital, maka aplikan animasi disebut aplikan digital. Penggunaan animasi dalam iklan layanan masyarakat ini ditampilkan dalam bentuk dua dimensi (2D). Media ini dapat menghibur karena tema yang disajikan selalu beragam dan inovatif sehingga dapat memberikan inspirasi bagi orang-orang yang menontonnya. Selain itu animasi juga digunakan sebagai media pembelajaran moral, khususnya bagi anak-anak yang sedang dalam masa pertumbuhan. Alasan pemilihan karya animasi, karena media ini dapat dinikmati oleh semua kalangan, umur, dan gender.

Iklan layanan masyarakat tentang keselamatan berkendara ini bertujuan untuk meningkatkan kesadaran masyarakat untuk selalu memperhatikan keselamatan saat berkendara, menjaga ketertiban lalu lintas dan menjadi hal yang baru untuk pemerintah dalam memberi himbauan, tentu ini menjadi sebuah solusi kreatif. Animasi dipilih sebagai media yang akan diterapkan dalam iklan layanan masyarakat tentang keselamatan berkendara menggunakan teknik motion graphic. Motion graphic adalah teknik untuk menggerakkan still images sehingga objek terlihat tidak membosankan, namun terlihat dinamis dan menarik. Terdapat dua metode dalam teknik ini, yakni dengan menggerakkan gambar, atau menggabungkan sequen gambargambar yang memiliki kontinuitas sehingga terlihat bergerak. Peneliti ini menggunakan teknik motion graphic karena ingin membuat video animasi yang menarik bagi masyarakat dan tentunya dapat meningkatkan kesadaran masyarakat dalam memperhatikan keselamatan dalam berkendara, selain itu teknik ini mudah dipahami atau digunakan dalam pembuatan video animasi dan tentunya tidak membutuhkan biaya banyak dalam pembuatannya. Hal inilah yang mendasari peneliti untuk melakukan penelitian tentang Pengembangan Video Iklan Layanan Masyarakat Mengenai Keselamatan Berkendara pada Polres Parepare Sebagai Media Informasi Menggunakan Teknik Motion Graphic dengan Swishmax 4.

\section{METODE PENELITIAN}

\section{A. Jenis Penelitian}

Penelitian ini menggunakan pendekatan penelitian dan pengembangan (Research \& Development). Adapun produk yang dikembangkan adalah Video Iklan Layanan Masyarakat Mengenai Keselamatan Berkendara pada Polres Parepare sebagai Media Informasi Menggunakan Teknik Motion Graphic dengan Swishmax 4.

\section{B. Tempat dan Waktu Penelitian}

Penelitian ini dilaksanakan di Kantor Kepolisian Resor (Polres) Parepare, yang beralamat di Jalan Andi Mappatola, Ujung Sabbang, Kec. Ujung, Kota Parepare, Sulawesi Selatan, Telepon (0421)-21020, Kode Pos 91114. Penelitian ini dilaksanakan pada bulan Januari - Maret 2020.

\section{Model Pengembangan}

Penelitian ini menggunakan model pengembangan 4D (four$D)$ merupakan model pengembangan perangkat pembelajaran. Model ini dikembangkan oleh S. Thiagarajan, Dorothy S. Semmel, dan Melvyn I. Semmel (1974). Model pengembangan 4D terdiri atas 4 tahap utama yaitu: define (pendefinisian), design (perancangan), develop (pengembangan) dan disseminate (penyebaran). Model ini dipilih karena dianggap memudahkan dalam proses penelitian dan pengembangan yang menghasilkan produk berupa video iklan layanan masyarakat, iklan yang dikembangkan kemudian diuji kelayakannya dengan validitas. yaitu:

Adapun model pengembangan 4-D terdiri atas 4 tahap utama

1. Tahap Pendefinisian (define)

Tahap pendefinisian berguna untuk menentukan dan mendefinisikan kebutuhan-kebutuhan didalam proses pembelajaran serta mengumpulkan berbagai informasi yang berkaitan dengan produk yang akan dikembangkan. Dalam tahap ini dibagi menjadi beberapa langkah yaitu:

a. Analisis Kebutuhan Data/Materi

Video animasi iklan layanan masyarakat bertujuan sebagai media yang digunakan tim sosialisasi Kepolisian Resor Kota Parepare untuk menyampaikan materi tentang keselamatan berkendara kepada masyarakat. Dalam analisis data/materi ini diperlukan observasi ke kantor untuk mendapatkan data/materi tentang prosedur/cara keselamatan dalam berkendara yang benar. Sehingga data/materi yang terkandung dalam video yang akan dikembangkan, diharapkan memiliki kesesuaian dengan kondisi yang terjadi di masyarakat kota Parepare.

b. Analisis Kebutuhan Fungsional

Video animasi memiliki fungsi utama dalam analisis kebutuhan fungsional, yaitu untuk menggambarkan ilustrasi prosedur keselamatan berkendara yang benar dalam bentuk 2 dimensi. Analisis kebutuhan fungsional dilakukan dengan cara observasi dari hasil analisis materi dan analisis media. Dari hasil observasi dan analisis akan diketahui objek apa saja yang dibutuhkan 2 dimensi.

c. Analisis Kebutuhan Perangkat Lunak

Perangkat Lunak utama yang diperlukan dalam pengembangan video animasi iklan layanan masyarakat ini adalah Swishmax 4. Dari analisis kebutuhan software dapat ditentukan spesifikasi hardware yang akan dibutuhkan agar software yang digunakan dapat berjalan dengan baik.

d. Analisis kebutuhan Perangkat Keras

Hardware yang digunakan untuk pemutaran video animasi ini yaitu PC/laptop, dan smartphone.

2. Tahap Perancangan (design)

Setelah mendapatkan permasalahan dari tahap pendefinisian, selanjutnya dilakukan tahap perancangan. Tahap perancangan ini bertujuan untuk merancang suatu video animasi iklan layanan masyarakat yang dapat digunakan sebagai media dalam sosialisasi Kepolisian Resor Kota Parepare.

\section{Tahap Pengembangan (develop)}

Tahap pengembangan ini bertujuan untuk menghasilkan video animasi yang sudah direvisi berdasarkan masukan ahli dan ujicoba kepada pengguna.

\section{Tahap Penyebaran (diseminate)}

Setelah ujicoba dan instrumen telah direvisi, tahap selanjutnya adalah tahap penyebaran. Tujuan dari tahap ini adalah menyebarluaskan video animasi iklan layanan masyarakat tentang keselamatan berkendara agar mengurangi terjadinya kecelakaan lalu lintas di jalan atau minimal masyarakat menyadari bahwa pentingnya memperhatikan keselamatan dalam berkendara. Pada penelitian ini hanya dilakukan diseminasi, yaitu dengan menyebarluaskan atau mempublikasikan produk akhir video iklan layanan masyarakat kepada masyarakat Kota Parepare. Publikasi produk dilakukan dengan memberikan kepada pihak Kepolisian Kota Parepare sebagai media untuk sosialisasi dan di-upload ke sosial media (youtube, facebook, Instagram, dan semisalnya) untuk penyebaran yang lebih luas. 


\section{Uji Coba Produk}

1. Desain produk

Konsep pembuatan produk dirancang berdasarkan hasil observasi, analisis kebutuhan, wawancara, dan data pendukung yang didapatkan di lapangan. Pengembangan media sosialisasi diawali dengan menyusun materi iklan layanan masyarakat. Langkah selanjutnya menyusun storyboard dan melakukan proses editing.

2. Subjek Produk

Tabel 1. Storyboard

\begin{tabular}{|c|c|c|}
\hline No & Scene / Gambar & Keterangan \\
\hline 1. & Intro & Pembukaan \\
\hline 2. & $\begin{array}{l}\text { KELENGKAPAN BERKENDARA } \\
\text { RODA DUA } \\
\text { helm } \\
\text { kos } 2 \text { ngan } \\
\text { sepatu }\end{array}$ & $\begin{array}{l}\text { Menjelaskan apa saja } \\
\text { kelengkapan yang dibutuhkan } \\
\text { saat berkendara roda dua }\end{array}$ \\
\hline 3. & RAAN & $\begin{array}{l}\text { Menjelaskan apa saja } \\
\text { kelengkapan kendaraan yang } \\
\text { harus di perhatikan }\end{array}$ \\
\hline 4. & $\begin{array}{l}\text { KELENGKAPAN KENDARAAN } \\
\text { RODA EMPAT }\end{array}$ & $\begin{array}{l}\text { Menjelaskan apa saja } \\
\text { kelengkapan yang dibutuhkan } \\
\text { saat berkendara roda empat }\end{array}$ \\
\hline 5. & KELENGKA & $\begin{array}{l}\text { Menjelaskan apa saja } \\
\text { kelengkapan kendaraan yang } \\
\text { harus di perhatikan }\end{array}$ \\
\hline 6. & KELENGKAPAN SURAT- SURAT & $\begin{array}{l}\text { Menjelaskan kelengkapan surat- } \\
\text { surat yang harus di bawa ketika } \\
\text { berkendara }\end{array}$ \\
\hline 7. & 9 & $\begin{array}{l}\text { Menjelaskan hal-hal yang harus } \\
\text { diperhatikan ketika berkendara : } \\
\text { Memperhatikan dan menaati } \\
\text { rambu lalu lintas } \\
\text { Selalu memperhatikan lampu } \\
\text { sein ketika berbelok }\end{array}$ \\
\hline 8. & 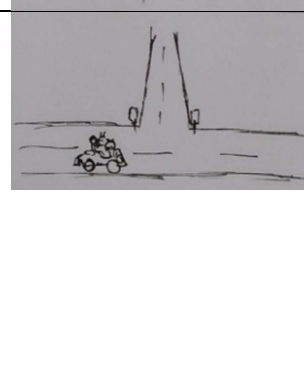 & $\begin{array}{l}\text { Menjelaskan hal-hal yang } \\
\text { dilarang ketika berkendara : } \\
\text { Dilarang menelfon ketika } \\
\text { berkendara } \\
\text { Menghindari berkendara di area } \\
\text { blind spot truk/bus } \\
\text { Tidak boleh berkendara } \\
\text { melebihi batas maksimum } \\
\text { kendaraan } \\
\text { Dilarang merokok ketika } \\
\text { berkendara }\end{array}$ \\
\hline 9. & Peringatan dan nasihat & $\begin{array}{l}\text { Berisi nasihat dan peringatan } \\
\text { bagi para pengendara kendaraan }\end{array}$ \\
\hline 10. & Outro & Penutup \\
\hline
\end{tabular}

3. Teknik Pengumpulan Data

Dalam penelitian dan pengembangan media pembelajaran menggunakan beberapa teknik pengumpulan data dari lapangan, penjabarannya adalah sebagai berikut:

a. Wawancara

Penulis melakukan wawancara dan bertanya langsung kepada salah satu staf/pegawai Satlantas Polres Kota Parepare yakni Briptu Radiman pada tanggal 25 November 2019 mengenai prosedur keselamatan berkendara yang benar, yang nantinya akan digunakan dalam pembuatan video animasi iklan layanan masyarakat.

b. Angket

Angket digunakan untuk mengumpulkan data dalam penelitian meliputi angket validasi media untuk validator. Angket ini diisi oleh ahli media dan ahli materi/konten dengan tujuan mengetahui kalayakan media sebelum diuji cobakan di lapangan. Serta angket tanggapan masyarakat yang diisi oleh masyarakat dengan tujuan mengetahui tanggapan masyarakat setelah melihat media.

c. Dokumentasi

Dokumentasi dilakukan dengan mengumpulkan dan menyimpan data yang diperoleh yaitu berupa dokumentasi foto implementasi, data angket validasi ahli, data/dokumen tentang safety riding dan laporan Laka Lantas (kecelakaan lalu lintas). Data yang dikumpulkan digunakan sebagai bukti sehingga penelitian dapat dipertanggung jawabkan kebenarannya.

\section{Jenis Data}

Jenis data yang digunakan yaitu data kuantitatif yang diperoleh dari penyebaran angket. Baik angket instrumen ahli media, ahli materi/konten, serta angket tanggapan masyarakat.

5. Instrument Penelitian

Instrumen penelitian yang digunakan pada penelitian ini berupa angket. Angket pada penelitian ini diberikan kepada ahli materi/konten, ahli media, dan masyarakat yang menjadi responden untuk memberikan tanggapan terhadap media yang telah dikembangkan

6. Validasi Insturment

Dalam penelitian kuantitatif kriteria utamanya adalah terdapat data hasil penelitian valid, reliabel, dan obyektif. Valid berarti instrumen tersebut dapat digunakan untuk mengukur apa yang hendak diukur. Validitas adalah derajat yang menunjukkan di mana suatu tes mengukur apa yang hendak diukur. Berdasarkan beberapa pendapat di atas dapat disimpulkan bahwa validitas adalah ketepatan dan kecermatan suatu tes dalam melakukan fungsi ukurannya.

Pada penelitian yang bersifat kuantitatif, untuk mendapatkan data yang valid dan reliabel yang diuji validitas dan realiabilitasnya adalah instrumen penelitiannya. Sebelum instrumen digunakan terlebih dahulu instrumen tersebut dikaji validitas isi (content validity) secara teoritik mengenai kesesuaian setiap butir instrumen dengan kriteria-kriteria yang akan diukur berdasarkan deskripsi teori yang relevan dengan cara meminta pendapat ahli (judgement expert). Maka dalam penelitian ini sebelum instrumen penilaian ahli materi, instrumen penilaian ahli media, dan instrumen tanggapan masyarakat digunakan di lapangan, sebelumnya dilakukan validasi instrumen oleh 2 orang ahli untuk memberikan pendapat layak tidaknya instrumen tersebut digunakan.

Berdasarkan data angket validasi instrument yang diperoleh, rumus yang digunakan untuk menghitung hasil angket dari validator adalah sebagai berikut:

$$
P=\frac{\Sigma x}{\Sigma x 1} \times 100 \%
$$


Keterangan :

$P \quad$ : Presentase yang dicari

$\sum \mathrm{X} \quad$ : Jumlah nilai jawaban responden

$\sum \mathrm{X}_{1} \quad$ : Jumlah nilai ideal

Sedangkan untuk mengambil kesimpulan yang disesuaikan dengan distribusi skor dan persentase terhadap kategori penilaian yang telah ditentukan. Tabel kriteria penilaian bisa dilihat pada Tabel berikut

Tabel 2. Kriteria Tingkat Kevalidan Instrument

\begin{tabular}{|c|c|}
\hline Persentase (\%) & Kriteria Validasi \\
\hline $76-100$ & Valid \\
\hline $56-75$ & Cukup Valid \\
\hline $40-55$ & Kurang Valid \\
\hline $0-39$ & Tidak Valid \\
\hline
\end{tabular}

Sumber : (Arikunto, 2006)

7. Teknik Analisis Data

Data yang akan dianalisis adalah data kuantitatif yang diperoleh dari angket penilaian validator ahli media, ahli materi, dan angket respon masyarakat. Data hasil penelitian terhadap kelayakan produk pengembangan media sosialisasi dianalisis secara deskriptif. Teknik analisis data yang diterapkan dalam penelitian dan pengembangan ini adalah dengan cara mengumpulkan data melalui instrumen-instrumen pengumpulan data, kemudian dianalisis dengan mengacu pada prosedur penelitian dan pengembangan.

Analisis data dilakukan setelah data dari seluruh responden atau sumber data lain terkumpul. Kegiatan dalam analisis data adalah mengelompokkan data, mentabulasi data, menyajikan data tiap variabel yang diteliti, dan melakukan perhitungan untuk menjawab rumusan masalah.

a. Analisis Data Uji Kelayakan

Analisis data ini dilakukan dengan teknik deskriptif yaitu menganalisis persentase kelayakan oleh ahli media dengan ahli materi dan hasil perhitungan skor persentase untuk masing-masing penilaian. Pada lembar validasi ahli media dan ahli materi jawaban setiap item pertanyaan menggunakan skala Guttman. Skala pengukuran dengan tipe ini akan di dapat jawaban yang tegas, yaitu ya-tidak, benar-salah, pernah-tidak pernah, positif-negatif. Selain dapat dibuat dalam bentuk pilihan ganda, juga dapat dibuat dalam bentuk checklist $(\sqrt{ })$ berdasarkan kategori penilaian pada Tabel.

\begin{tabular}{|c|c|c|}
\hline \multicolumn{3}{|c|}{ Tabel 3. Kategori Penilaian Skala Guttman } \\
\hline NO. & Skor & Keterangan \\
\hline 1. & 1 & Setuju/Ya \\
\hline 2. & 0 & Tidak Setuju/Tidak \\
\hline
\end{tabular}

Pengujian ini menggunakan teknik analisis statistik deskriptif di mana analisis ini diperlukan agar dapat menjelaskan suatu data dengan mendeskripsikannya, sehingga didapatlah kesimpulan dari sekelompok data tersebut. Dalam analisis kelayakan produk ini, digunakan penghitungan sebagai berikut:

$$
\text { Persentase kelayakan }=\frac{\text { skor yang diobservasi }}{\text { skor yang diharapkan }} \times 100 \%
$$

Selanjutnya mengambil kesimpulan yang disesuaikan dengan distribusi skor dan persentase terhadap kategori penilaian yang telah ditentukan. Tabel 3.11 merupakan tabel persentase kelayakan media.
Tabel 4. Tabel Persentase penilaian kelayakan

\begin{tabular}{|c|c|}
\hline Persentase Penilaian & Kriteria \\
\hline $81 \%-100 \%$ & Sangat Layak \\
\hline $61 \%-80 \%$ & Layak \\
\hline $41 \%-60 \%$ & Kurang Layak \\
\hline $21 \%-40 \%$ & Tidak Layak \\
\hline $0 \%-20 \%$ & Sangat Tidak Layak \\
\hline
\end{tabular}

b. Analisis Data Uji Tanggapan Pengguna

Analisis ini dilakukan dengan menggunakan metode kuesioner atau angket. Penilaian data tanggapan pengguna ini menggunakan penilaian skala likert dengan rentang nilai 1 sampai 5 berdasarkan dengan kriteria penilaian seperti pada Tabel.

\begin{tabular}{|c|c|} 
Tabel 5. Kriteria Penilaian Skala Likert \\
\hline Jawaban & Skor \\
\hline Sangat Baik & 5 \\
\hline Baik & 4 \\
\hline Cukup Baik & 3 \\
\hline Tidak Baik & 2 \\
\hline Sangat Tidak Baik & 1 \\
\hline Sumber: (Sugiyono, 2018)
\end{tabular}

Data yang terkumpul dianalisis dengan teknik analisis deskriptif kuantitatif yang diungkapkan dalam distribusi frekuensi dan persentase terhadap kategori skala penilaian yang telah ditentukan dari penyajian dalam bentuk persentase. Untuk keperluan analisis kuantitatif maka jawaban pada skala Likert dapat diberi skor tentang pernyataan positif yaitu:

1. Sangat Setuju (SS) diberi skor 5

2. Setuju (S) diberi skor 4

3. Ragu-ragu (RR) diberi skor 3

4. Tidak Setuju (TS) diberi skor 2

5. Sangat Tidak Setuju (STS) diberi 1

Skor tersebut dihitung menggunakan rumus konversi ke presentase skor. Berikut ini adalah rumus konversi ke persentase skor.

$$
\text { Persentase responden }=\frac{\text { Skor Perolehan }}{\text { Skor Maksimal }} \times 100 \%
$$

Selanjutnya, mengkonversikan skor rata-rata yang diperoleh menjadi nilai kualitatif sesuai kriteria penilaian (Sugiyono, 2014) dalam tabel berikut:

Tabel 6. Tabel Klasifikasi Penilaian

\begin{tabular}{|c|c|}
\hline Rentang skor & Kriteria \\
\hline $81 \%-100 \%$ & Sangat baik \\
\hline $61 \%-80 \%$ & Baik \\
\hline $41 \%-60 \%$ & Cukup Baik \\
\hline $21 \%-40 \%$ & Kurang \\
\hline$>20 \%$ & Sangat kurang \\
\hline
\end{tabular}

Sumber : (Sugiyono, 2014) 


\section{HASIL DAN PEMBAHASAN}

\section{A. Hasil Penelitian}

Penelitian yang telah dilakukan adalah penelitian pengembangan produk sesuai dengan tahapan pengembangan yang telah ditentukan. Kemudian dari penelitian ini dapat diketahui kelayakan iklan layanan masyarakat yang telah dikembangkan dan diketahui respon pengguna terhadap iklan layanan masyarakat, hingga iklan layanan masyarakat siap digunakan dalam proses sosialisasi.

Berikut ini adalah penjabaran langkah-langkah yang dilakukan peneliti dalam mengembangkan video animasi iklan layanan masyarakat menggunakan teknik Motion Graphic dengan 4-D model.

1. Define (Pendefinisian)

Tahapan ini dilakukan melalui lima langkah pokok, yaitu; analisis kebutuhan data/materi, analisis fungsional, analisis masyarakat, analisis software dan hardware.

2. Design (Perancangan)

Tujuan tahapan ini adalah untuk merancang dan menghasilkan suatu video animasi iklan layanan masyarakat produk yang akan dikembangkan. Adapun langkah-langkah dalam tahap perancangan ini adalah menyusun materi, perancangan gambar animasi 2D, background, dan jenis huruf (font) dan penyusunan kisi-kisi instrumen penilaian kelayakan dan tanggapan media.

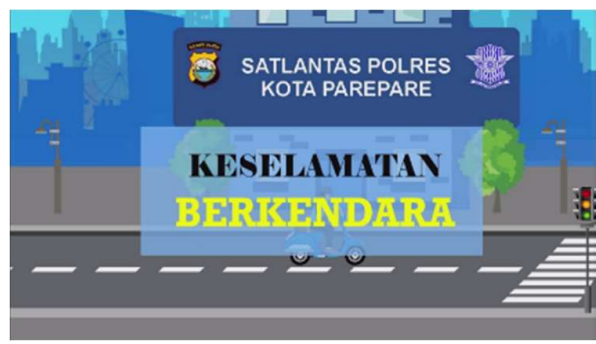

Gambar 1. Scene 1

Pada scene 1 ini adalah pembukaan (intro) pada video iklan layanan masyarakat yang berjudul keselamatan berkendara.

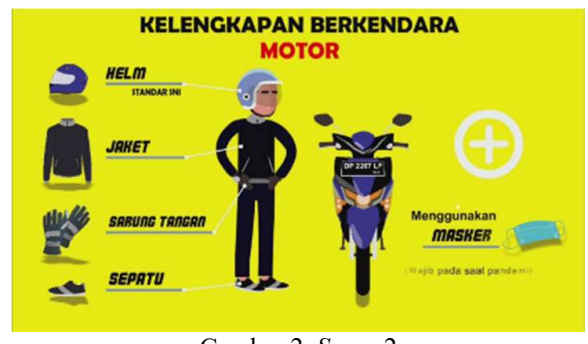

Gambar 2. Scene 2

Pada scene 2 ini, pemaparan tentang kelengkapan apa saja yang dibutuhkan saat berkendara untuk kendaraan roda 2 yang termasuk dalam prosedur keselamatan dalam berkendara.

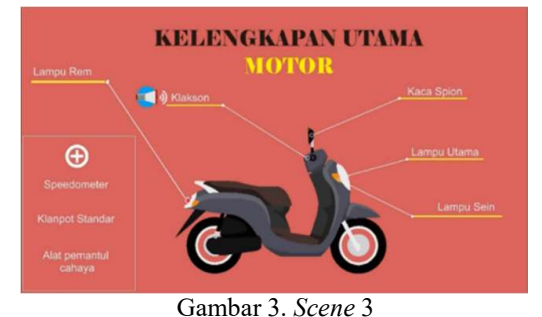

Pada scene 3 ini, di sebutkan tentang kelengkapan utama kendaraan roda 2 yang harus diperhatikan ketika akan berkendara.

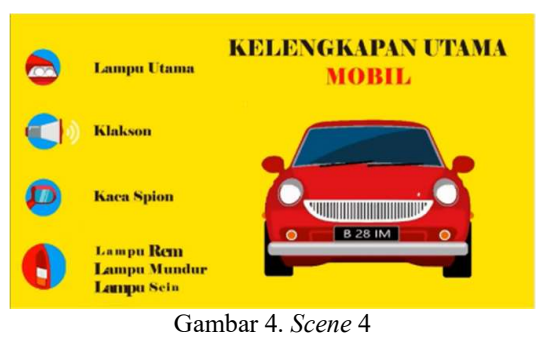

Pada scene 4 ini, disebutkan tentang kelengkapan utama kendaraan roda 4 yang harus diperhatikan ketika akan berkendara.

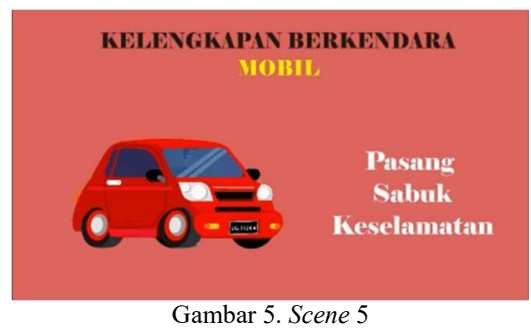

Pada scene 5 ini, dijelaskan agar selalu memperhatikan kelengkapan berkendara kendaraan roda 4 yaitu memasang sabuk pengaman ketika akan berkendara.

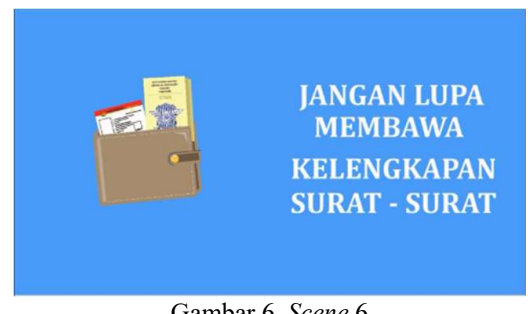

Pada scene 6 ini, pengingat agar selalu membawa surat-surat kelengkapan kendaraan anda sebelum berkendara.

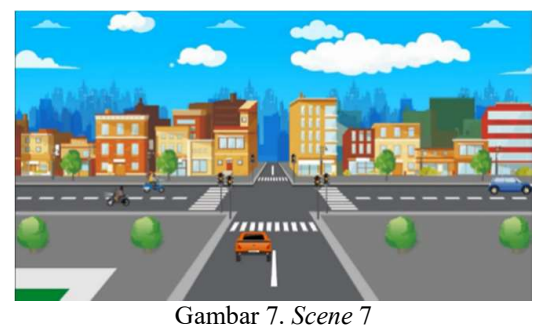

Pada scene 7 ini, di jelaskan tentang hal-hal yang harus diperhatikan ketika berkendara yaitu agar selalu memperhatikan dan menaati rambu-rambu lalu lintas dan agar selalu memperhatikan lampu sein ketika akan berbelok.

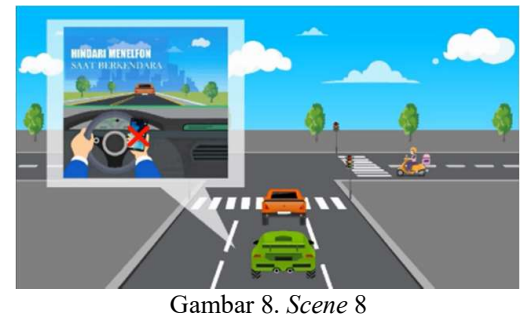

Pada scene 8 ini, dipaparkan tentang hal-hal yang tidak boleh dilakukan ketika berkendara, salah satunya yaitu menghindari menggunakan alat komunikasi ketika berkendara. 


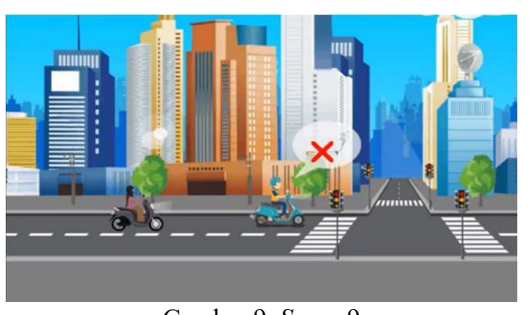

Gambar 9. Scene 9

Pada scene 9 ini, dipaparkan tentang hal-hal yang tidak boleh dilakukan ketika berkendara, salah satunya yaitu larangan merokok ketika sedang berkendara.

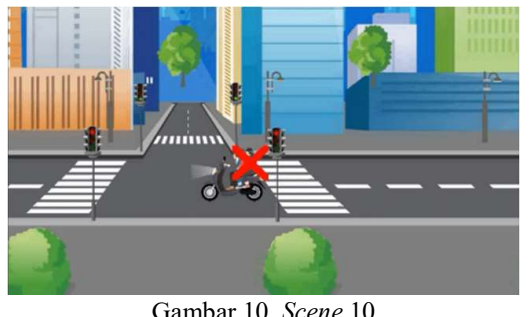

Pada scene 10 ini, dipaparkan tentang hal-hal yang tidak boleh dilakukan ketika berkendara, salah satunya yaitu larangan untuk berkendara melebihi batas kapasitas kendaraan.

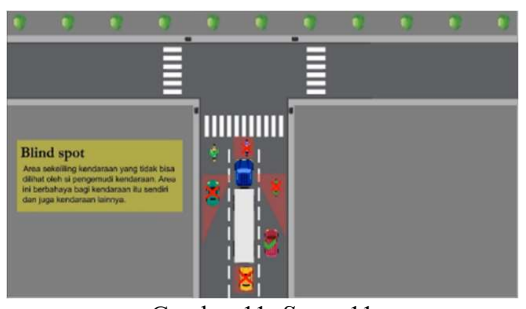

Gambar 11. Scene 11

Pada scene 11 ini, dipaparkan tentang hal-hal yang tidak boleh dilakukan ketika berkendara, salah satunya yaitu menghidari berkendara di area blind spot roda 8 atau lebih seperti truk dan bus.

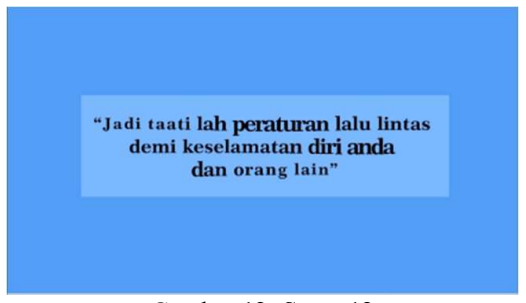

Gambar 12. Scene 12

Pada scene 12 ini, berisikan nasihat untuk semua pengendara untuk selalu memperhatikan dan mematuhi segala peraturan lalu lintas demi keselamatan diri dan orang lain.

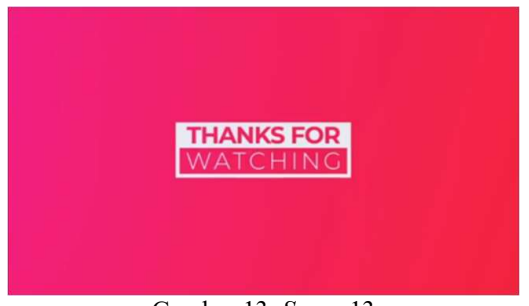

Gambar 13. Scene 13

Pada scene 13 ini yang merupakan scene terakhir atau outro dalam pembuatan media video sosialisi tentang keselamatan berkendara, berisi tentang profil dari pembuat media sosialisasi.

3. Develop (Pengembangan)

Tahap pengembangan ini bertujuan untuk mengembangkan video animasi iklan layanan masyarakat hingga valid dan layak dipakai. Langkah-langkah yang ditempuh oleh peneliti dalam tahap ini adalah validasi materi dan media pengembangan. Langkah ini bertujuan untuk mendapatkan masukan dan saran guna menyempurnakan media serta materi pada iklan layanan masyarakat.

\section{Disseminate (Penyebaran)}

Pada tahap penyebaran, video animasi iklan layanan masyarakat yang telah dikembangkan kemudian diterapkan pada kondisi yang sebenarnya. Iklan akan diujicobakan kepada masyarakat pada tahap uji pengembangan yang terdiri dari uji coba kelompok kecil dan uji coba lapangan (field trying). Uji coba dilakukan untuk mengetahui pendapat masyarakat terhadap video animasi iklan layanan masyarakat. Uji coba dilakukan kepada masyarakat setelah proses revisi dan telah dinilai oleh validator. Uji coba kelompok kecil dan uji coba lapangan dilakukan pada masyarakat Kota Parepare. Tujuan dan fungsi dari iklan ini dijelaskan kepada masyarakat terlebih dahulu. Masyarakat juga diberikan angket untuk dimintai respon/pendapat. Data kelayakan berdasarkan tanggapan responden diperoleh dari angket sebanyak 20 butir pernyataan dengan jumlah 6 orang untuk uji coba kelompok kecil pada tanggal 5 Februari 2021 dan 30 orang dari masyarakat untuk uji coba lapangan pada tanggal 8 Februari 2021.

\section{B. Pembahasan}

Berdasarkan hasil penelitian dihasilkan sebuah video animasi iklan layanan masyarakat tentang keselamatan berkendara menggunakan teknik motion graphic sebagai media sosialisasi. Video ini dikembangkan dengan menggunakan model pengembangan 4-D. Dengan model tersebut dapat dihasilkan media pembelajaran yang baik dan layak untuk digunakan.

Berdasarkan analisis data hasil penelitian, diperoleh hasilhasil penilaian yang dapat dijabarkan dalam pembahasan sebagai berikut:

1. Ahli Materi

Berdasarkan penilaian ahli materi, kelayakan media video iklan layanan masyarakat mencapai nilai total sebesar adalah 25 dari jumlah skor ideal yang diharapkan berdasarkan jumlah pernyataan pada angket adalah 26 . Sehingga, persentase kelayakan skor total butir pernyataan dari seluruh aspek adalah $=25 / 26 x$ $100 \%=96,15 \%$ sehingga termasuk dalam kategori "Sangat Layak". Hal ini dapat diartikan bahwa ahli materi menyatakan bahwa media video iklan layanan masyarakat menganai keselamatan berkendara dalam kategori "layak" digunakan sebagai media sosialisasi. Namun, meskipun demikian tidak menutup kemungkinan nantinya perlu dilakukan revisi sesuai dengan saran dari para ahli materi.

\section{Ahli Media}

Berdasarkan penilaian ahli media, kelayakan media video iklan layanan masyarakat mencapai nilai total sebesar adalah 32 dari jumlah skor ideal yang diharapkan berdasarkan jumlah pernyataan pada angket adalah 32 . Sehingga, persentase kelayakan skor total butir pernyataan dari seluruh aspek adalah aspek adalah $=32 / 32 \times 100 \%=100 \%$ sehingga termasuk dalam kategori "Sangat Layak". Hal ini dapat diartikan bahwa ahli media menyatakan bahwa media video iklan layanan masyarakat mengenai keselamatan berkendara dalam kategori "Sangat Layak" digunakan sebagai media sosialisasi. Namun, meskipun demikian tidak menutup kemungkinan nantinya perlu dilakukan revisi sesuai dengan saran dari para ahli media. 


\section{Uji Coba}

Berdasarakan uji coba kelompok kecil dan uji coba lapangan media video iklan layanan masyarakat menganai keselamatan berkendara yang dilakukan terhadap masyarakat Kota Parepare. Data yang diperoleh dari uji coba kelompok kecil yang dilakukan oleh 6 responden, 3 responden memberikan respon sangat baik, 3 responden memberikan respon baik, serta tidak satupun responden memberikan respon cukup baik, tidak baik, dan sangat tidak baik. Jika dipersentasekan $50 \%$ masyarakat memberikan respon sangat baik, 50\% masyarakat memberikan respon baik, $0 \%$ masyarakat memberikan respon cukup baik, $0 \%$ masyarakat memberikan respon tidak baik, dan $0 \%$ masyarakat memberikan respon sangat tidak baik. Data yang diperoleh dari uji coba lapangan yang dilakukan oleh 30 orang responden, 22 masyarakat memberikan respon sangat baik, 8 memberikan respon baik, tidak ada satupun yang memberikan respon cukup baik, respon tidak baik, dan respon sangat tidak baik. Jika dipersentasekan $73,33 \%$ masyarakat memberikan respon sangat baik, 26,67\% masyarakat memberikan respon baik, tidak satupun yang memberikan respon cukup baik, respon tidak baik, dan respon sangat tidak baik. Dari data tersebut dapat diartikan bahwa media video iklan layanan masyarakat mengenai keselamatan berkendara di Satlantas Kota Parepare mendapatkan respon positf dari masyarakat.

Berdasarkan hasil pengujiann yang telah dilakukan maka disimpulkan bahwa keseluruhan aspek yang diuji telah memenuhi standar kualitas iklan layanan masyarakat sebagai media sosialisasi yang diharapkan. Hasil pengujian ini juga merepresentasikan jaminan kualitas produk yang dikembangkan sehingga dinyatakan dapat diimplementasikan pada media yang sesungguhnya.

\section{A. Kesimpulan}

\section{KESIMPULAN DAN SARAN}

Pengembangan video iklan layanan masyarakat melalui beberapa tahap antara lain: (a) Pendefinisian (define), pada tahap pedefinisian ini, yang dilakukan antara lain adalah menentukan tujuan pembuatan media, menganalisis sasaran pengguna media, dan analisis kebutuhan software dan hardware pembuatan media. (b) Perancangan (desain), yang dilakukan dalam tahap ini yaitu pembuatan storyboard, penyusunan materi, pengumpulan bahan berupa gambar, musik, font dan sebagainya. Media dirancang menggunakan aplikasi Swishmax 4. (c) Pengembangan (develop), tahap ini merupakan pengujian media pembelajaran dilakukan oleh ahli materi dan ahli media. (d) Penyebaran (disseminate), pada tahap ini dilakukan pengujian terhadap pengguna akhir media yaitu uji coba kelompok kecil sebanyak 6 orang masyarakat Kota Parepare dan uji coba lapangan sebanyak 30 orang masyarakat Kota Parepare.

Video Iklan layanan masyarakat mendapatkan respon positif dari masyarakat dengan perolehan data $73,33 \%$ responden memberikan respon sangat baik, $26,67 \%$ responden memberikan respon baik, $0 \%$ responden memberikan respon respon cukup baik, tidak baik dan sangat tidak baik. Sehingga dapat diartikan media video iklan layanan masyarakat yang dikembangkan dinyatakan layak untuk digunakan sebagai media sosialisasi.

\section{B. Saran}

Berdasarkan hasil penelitian, pembahasan dan kesimpulan di atas, maka saran yang dapat diberikan pada penelitian ini adalah:

1. Sesuai dengan hasil penelitian, bahwa iklan layanan masyarakat yang dikembangkan layak untuk digunakan oleh Satlantas Kota Parepare sebagai media sosialisasi. Oleh karena itu video iklan layanan masyarakat diharapkan dapat diterapkan untuk masyarakat luas khususnya masyarakat di Kota Parepare.
2. Diharapkan adanya penelitian lebih lanjut terhadap efektivitas penggunaan iklan layanan masyarakat sebagai media sosialisasi di Kota Parepare, sehingga dapat mengurangi masalah laka lantas di Kota Parepare.

\section{DAFTAR PUSTAKA}

[1] Dwihantoro, P. (2010). Perancangan iklan layanan masyarakat sebagai kampanye pelestarian hutan mangrove di daerah Tugu Semarang. Universitas Negeri Malang.

[2] Fisu, A. A. (2019). Tinjauan Kecelakaan Lalu Lintas Antar Wilayah Pada Jalan Trans Provinsi Sulawesi Selatan. Jurnal Ilmiah Ilmu-Ilmu Teknik.

[3] Sugiyono. 2013. Metode Penelitian Pendidikan. Bandung: Alfabeta.

[4] Sugiyono. 2014. Metode Penelitian Pendidikan. Bandung: Alfabeta.

[5] Venus dalam Kunarto. (2004). Analisis Data Personil dan Dimensi Permasalahannya Dalam Rangka Menunjang. Jakarta: Cipta Manunggal.

[6] Widisindia, A. D., \& Chidtian, A. S. (2014). Iklan Layanan Masyarakat Keselamatan Dalam Berkendara Jalur Pantura Dan Sekitarnya . Createvitas. 